上で圧力曲線が一致することは，この範囲の反応が汇とんど平衡

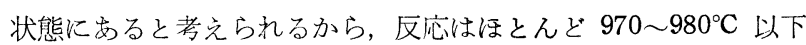
で進行している。このことは前報6)で四塩化ケイ素大過剩の場合, 還元反応と $1100^{\circ} \mathrm{C}$ 以上で生ずる不均化反応とは重複しないこと を確認したが，これと同椂に本実験の約 $30 \%$ 亚鉛過剩扣よび理 論比配合の組成*7の場合にも両反応は重複しないことを認めた。

以上の結果，約 $30 \%$ 亜鉛過剩扣よび理論比配合のいずれの場 合も $900^{\circ} \mathrm{C}$ 以下で還元反応の大部分が進行し, 約 $950^{\circ} \mathrm{C}$ 以上で は理想気体の法則が適用できる気相反忘であった。

\section{$5 \cdot 2$ 反応速度}

反応速度の測定温度範团を亚鉛の沸点以上および $1100^{\circ} \mathrm{C}$ 以下 としたが，これは気相反応でしかも $1100^{\circ} \mathrm{C}$ 以上の不均化反応を ともなわない温度範囲としたためで女る。ここで亜鉛の圧力曲線 の屈折点を $970^{\circ} \mathrm{C}$ とすと，この温度以上の反応が気相反応とな

*7 表 1 3 の原料組成
り, 反応速度式の成立する温度範囲 $\left(980 \sim 1065^{\circ} \mathrm{C}\right)$ と一致する。 すなわちこの屈折点の $970^{\circ} \mathrm{C}$ 以上が理想気体の法則が適用できる 範囲となり，压力曲線より推定した温度をより正確に修正する結 果となった。事実, $950^{\circ} \mathrm{C}$ 付近の測定を行なってみたが，一定の 速度定数が得られなかったので表 4 の測定結果より除いた。

この速度式が成立つことは衰鉛が単原子分子の状態で反応する ことになる。Hildebrand ${ }^{7}$ によれば亚鉛の蒸気の大部分は単原子 分子で，ごく一部分が $2 \mathrm{Zn} \rightleftarrows \mathrm{Zn}_{2}$ の重合状態にある。そして この重合度は $100^{\circ} \mathrm{C} て ゙ ~ 4 \%$ の值を示し，高温ではさらに少なく なると報告している。よって反応速度式はこの点に和いても矛盾 していない。

（昭和 39 年 11 月 15 日，学協会連合 10 回大会講演発表， 昭和 40 年 4 月 4 日，日本化学会第 18 年会講演発表）

7）松浦，“無機化学全書 UII-1”， 九善（1962） p. 253

\title{
塩類濃縮における脱塩室濃度の影響*1
}

(昭 和 40 年 12 月 4 日受理)

田坂 雅 保・香川 毓美*2

塩類の電解濃縮に関する関係式を第 1 報で報告したが，その中に含まれているイオン交換膜の特性，すなおち輸率，イオンに随 伴して動く水量，イオンや水の見かけの拡散係数は一般的には外液濃度に依存する。

そこで架橋度の低いイオン交換体と塩化ビニルを使用して，外液浀度の影響を受けやすい不均質膜を作製し，脱塩窒濃度扰よび 電流密度を变化させて定常濃縮を行ない，外液涪度による膜の特性の变化を調べた。その絬果ただ脱盐室濃度を一定に保てば，膜 の特性は注注一定として取り扱えることが明らかとなった。

\section{1 緒言}

イオン交換膜を使用して程類を電解濃縮する埸合, 電解質と水 の移動について次式が成立することを第 1 䇑1)で報告した。

$$
\begin{gathered}
Q_{s}=\frac{\eta S I}{F}-D_{s} S \Delta \mu_{ \pm} \\
Q_{0}=h_{S} Q_{s}+D_{0} S \Delta P
\end{gathered}
$$

ここで, $Q_{S}$ : 電解質の移動量, $Q_{0}:$ 水の移動量, $S:$ 有効膜面積, $I:$ : 晻流密度, $\Delta \mu_{ \pm}$: 平均の化学ポテンシャル差, $\Delta P$ : 浸透圧差, $\eta$ : 電流効率, $h_{s}$ : 単位電解質むたりの随伴水量, $D_{s}$ : 電解質の 見かけの拡散定数, $D_{0}$ : 水の見かけの拡散定数である。しかし脱 塩室濃度が低くなると上式の適合性は悪くなり, そのことは水の 移動に関する（2）式において顕著であった。

一般にイオン交換膜に括いては, 外液濃度の変化により膜内濃 度が変化するので, 䋏密には膜の諸性質, $\eta, h_{s}, D_{s}, D_{0}$ も外液 濃度の変化により変化すると考光られる。（1）, (2) 式の誘導に は注とんど仮定は含まれていないから，この膜の特性の変化が

*1 本報を「イオン交換膜による塩類濃縮の研究(第 4 報)」と する。前報(第 3 報), 田坂, 平井, 香川, 工化, 68,1655 (1965).

*2 Masayasu TASAKA, Ikumi KAGAWA 名古屋大学工学 部応用化学教室 : 名古屋市千種区不老町.

1) 田坂, 香川, 工化, 68, 1646 (1965).
（1），（2）式と実験との不一致を引き起こするのと想像される。 本報に扣いては架橋度の小さいイオン父換樹脂を用いて膨潤しや すいイオン交換膜を調製し，外液漹度により膜の性質が変化する 場合の電解濃縮の条件を明らかにしょうとするものでせる。

膜の性質は溶液の重心移動の方向によって大きく変化すること が Teorel12), Frank ${ }^{3)}$, Kobatake ら ${ }^{4)}$ によって指摘されている が，電解濃縮の場合には溶液は常に脱塩窒から濃縮室に向って流 れている。したがって電解濃縮の場合には脱塩室濃度一定という 条件で膜の特性が一定となり，(1)，（2）式がよく奏験に適合す ることが示される。

\section{2 実験}

\section{$2 \cdot 1$ 膜}

イオン交換体として DVB 2\%で架橋された非常に架橋度の小 さい Dowex 50 W-X 2 (カチオン交換体) と Dowex 1-X 2（ア ニオン交換体）を 300 mesh 以下に粉砕して使用し，結合剤とし てポリ塩化ビニル (5\% 酢酸ビニル其重合体, 平均重合度 800) を使用した。膜はイオン交換体と壏化じニルを6対 4 の割合で配

2) T. Teorell, J. Gen. Physiol, 42, 831, 847 (1959).

3) U. F. Frank, Ber. Bursenges. Phys. Chem., 67, 657 (1963).

4) Y. Kobatake, H. Fujita, J. Chem. Phys., 40, 657 (1963). 
合してロール法により製膜し，さらに加 熱加王成形して作製した。膜の調製のと き使用した可塑剂はメタノール中で完全 に抽出除去して使用した。脱可塑剤を行 ならとき，膜のメタノール中での膨潤度 が大であるため破損しやすく膜の作製は 困難であった。しかし一度でき上った膜 は安定で，電解濃縮垁験中に破損する上 うなことはなかった。膜の厚さはカチオ

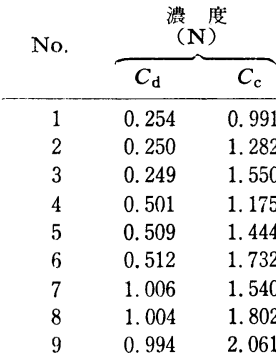
ン交換膜 $0.24 \mathrm{~mm}$, アニオン交換膜 $0.26 \mathrm{~mm}$ でせった。

\section{$2 \cdot 2$ 輸 率}

次式のようなセルを構成し，その膜電位測定から膜の静的輸率 学求めた。そのときの膜の両側の平均濃度が脱塩室濃度 0.25 , $0.5,1 \mathrm{~N}$ になる上 5 に，溶液濃度は $1 / 6$ と $1 / 3,1 / 3$ と $2 / 3$, $2 / 3$ と $4 / 3 \mathrm{~N}$ とした。

$\mathrm{Hg}\left|\mathrm{Hg}_{2} \mathrm{Cl}_{2}\right| \mathrm{KCl}|\mathrm{NaCl}|$ 膜 $|\mathrm{NaCl}| \mathrm{KCl}\left|\mathrm{Hg}_{2} \mathrm{Cl}_{2}\right| \mathrm{Hg}$

鼬度 satd. $\mathrm{c}(1) \quad \mathrm{c}(2)$ satd.

膜表面の执散層を除くためには溶液を膜に吹きつけるように流 して行なっだ)。

\section{$2 \cdot 3$ 濃縮装置}

第 1 報 ${ }^{1)}$ と同様に濃縮室 3 室と脱塩室 4 室(電極室 2 室を含む) の 7 室からなるメタクリル樹脂製の装置を用いたが，大きな膜の 作製が困難なため小型装置を使用した。各室は円筒型をしており その直径は $6 \mathrm{~cm}$, 中央 5 室の膜間距離は $0.9 \mathrm{~cm}$ であり, 電極 室の幅は $1.5 \mathrm{~cm}$ である。電極室の流速は電流密度により 60〜 $160 \mathrm{~cm}^{3} / \mathrm{min}$ とし, 脱塩空の流速は $30 \sim 65 \mathrm{~cm}^{3} / \mathrm{min}$ とした。

\section{$2 \cdot 4$ 実験方法}

電解質溶液の濃縮は第 1 報と同様に脱塩室には所定濃度の塩化 ナトリウム溶液を流し, 濃縮室には膜を通過して入る溶液以外に 外部からの液の注入は行なわなかった。測定は中央 3 室について 行なった。脱塩室濃度はその 2 窒の平均值を使用したが，両者は 実験誤差内で一致していた。所定電流を通じたときの電解質と水 の移動量を求めるためには, 脱塩室から濃縮室へ移動した液量を overflow させその液量と濃度を測定して求めた。な拝定常状態 の值は，時間の経過にかかわらず濃度変化のなくなった值を採用 した。

\section{3 結果および考察}

カチオン交換膜とアニオン交換膜の静的輸率の濃度による変化 堂示すと表 1 のようになる。平均濃度が $0.25 \mathrm{~N}$ から $1 \mathrm{~N}$ に変 わると輸率は外部溶液の濃度の影響を受けて 0.9 から 0.7 へと 大きく变化している。ここで輸率 $t_{ \pm}$は

$$
-\Delta F= \pm\left(2 t_{ \pm}-1\right) \frac{R T}{F} \ln \frac{a_{ \pm}(2)}{a_{ \pm}(1)}
$$

表 1 静 的輸 率

\begin{tabular}{|c|c|c|c|}
\hline$c(1)$ & $c(2)$ & $\begin{array}{c}t_{+} \text {(カチオオ } \\
\text { 交换膜) }\end{array}$ & $\begin{array}{l}t_{\text {- }}(\text { (ア }=才 \\
\text { ン交換膜) }\end{array}$ \\
\hline 0.174 & 0.353 & 0.90 & 0.86 \\
\hline 0.350 & 0.708 & 0.80 & 0.79 \\
\hline $0.70 \%$ & 1.411 & 0.70 & 0.70 \\
\hline
\end{tabular}

5) M. Nagasawa, I. Kagawa, Discussion Faraday Soc., 21,52 (1956).
表 2 実験条件および結果

\begin{tabular}{|c|c|c|c|c|c|c|}
\hline $\begin{array}{l}\text { 電流密度 } \\
\left(\mathrm{A} / \mathrm{dm}^{2}\right)\end{array}$ & $\begin{array}{l}\text { 浱縮液量 } \\
(\mathrm{m} l / \mathrm{hr})\end{array}$ & $\begin{array}{c}D_{s} \\
(\mathrm{meq} / \\
\mathrm{dm}^{2} \cdot \mathrm{hr} \cdot \\
l \cdot \mathrm{atm})\end{array}$ & $\begin{array}{c}D_{0} \\
\left(\mathrm{~g} / \mathrm{dm}^{2} \cdot\right. \\
\mathrm{hr} \cdot \mathrm{atm})\end{array}$ & $\underset{(\mathrm{mol} /}{H_{s}}$ & $\eta$ & $\begin{array}{r}\eta_{\text {calc }} \\
\left(t_{+}^{*}++t t_{-*}^{*}\right. \\
-1)\end{array}$ \\
\hline 1 & 5.72 & & & & & \\
\hline 2 & 9.75 & 0.21 & 0.33 & 22.7 & 0.72 & 0.87 \\
\hline 4 & 18. 12 & & & & & \\
\hline 1 & 4. 28 & & & & & \\
\hline 2 & 8.04 & 0.42 & 0.26 & 21.3 & 0.70 & 0.79 \\
\hline 4 & 15.18 & & & & & \\
\hline 1 & 3.21 & & & & & \\
\hline 2 & 6.00 & 0.53 & 0.18 & 18.7 & 0.62 & 0.75 \\
\hline 4 & 11.22 & & & & & \\
\hline
\end{tabular}

を用いて求めた。 $\Delta \Psi$ は電位差， $R$ は気体定数， $T$ は絶対温度， $a_{ \pm}$は平均活量である。

脱塩室濃度 $C_{\mathrm{d}}=0.25,0.5,1 \mathrm{~N}$ について電流密度 I を 1,2 , $4 \mathrm{~A} / \mathrm{dm}^{2}$ と変化させて電解濃縮を行なった結果を表 2 に示す。膜 のイオン交換体の架橋度が小さいため濃縮室濃度は第 1 報の值の 約半分ぐらいで非常に低い值を示している。これらの結果に(1) 式を適用して図示すると因 1 がえられる。DVB 約 $8 \%$ を) を含む イオン交換樹脂を使用した前報の実験に沶いては脱塩室および濃 縮室濃度による $D_{s}, \eta$ の变化は無視できた。しかし膨潤度の大き い膜を使用した本実験結果では $D_{s}, \eta$ は電流密度の変化に基づく 濃縮室濃度 $C_{\mathrm{c}}$ には依存しないが, 脱塩室濃度 $C_{\mathrm{d}}$ により大きく 変化している。 $C_{\mathrm{d}}$ が一定のとき $C_{\mathrm{c}}$ が变化しても輸率が变化し ないということは Kressman と Tye ${ }^{7)}$ が $C_{\mathrm{d}}=0.5 \mathrm{~N}$ について 行なった結果と一致する。また $D_{s}$ の值は前報に比べて非常に大 きく自由抆散による影響が大であることを示している。 水の移動量について (2) 式を適用し, 横軸に $Q_{s} / \Delta P$, 縦軸に $Q_{0} / \Delta P$ を取って図示すると図 2 となる。 $D_{0}$ の值は $0.184 \sim 0.32$ ऽ $\left(\mathrm{g} / \mathrm{hr} \cdot \mathrm{dm}^{2} \cdot \mathrm{atm}\right)$ と第 1 報の $0.005 \sim 0.039$ と比較して約 5〜1C 倍以上である。そして電解質の移動の場合々同様 $C_{\mathrm{d}}$ が一定であ

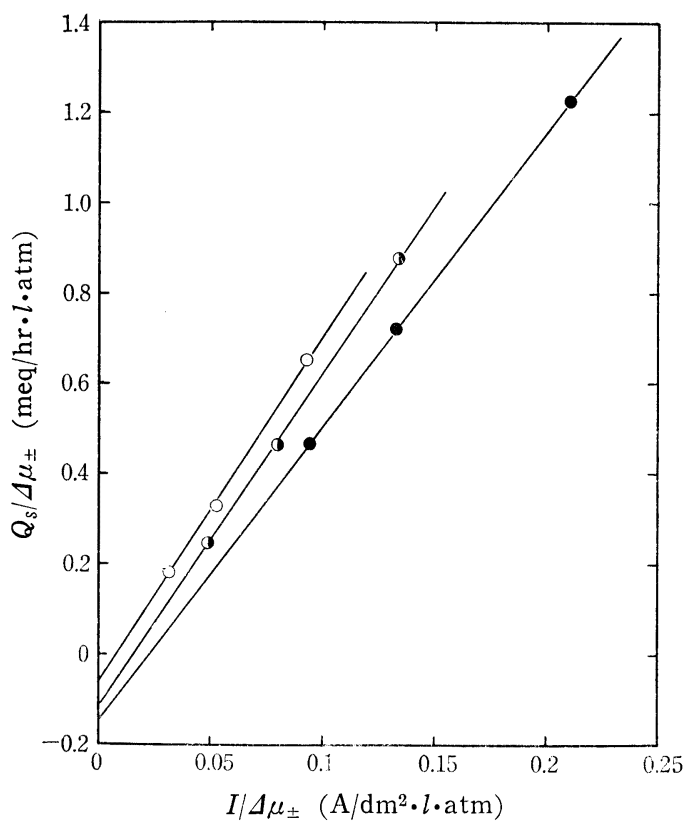

図 1 関係式 (1) とよる実験結果の解析

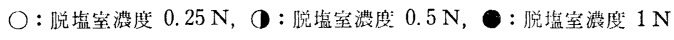

6) F. Helfferich, "Ion Exchange", McGraw-Hill Book Co. Inc., New York (1962) p. 574.

7) T. R.E.Kressman, F. L. Tye, Discussion Faraday Soc., 21, 185 (1956). 


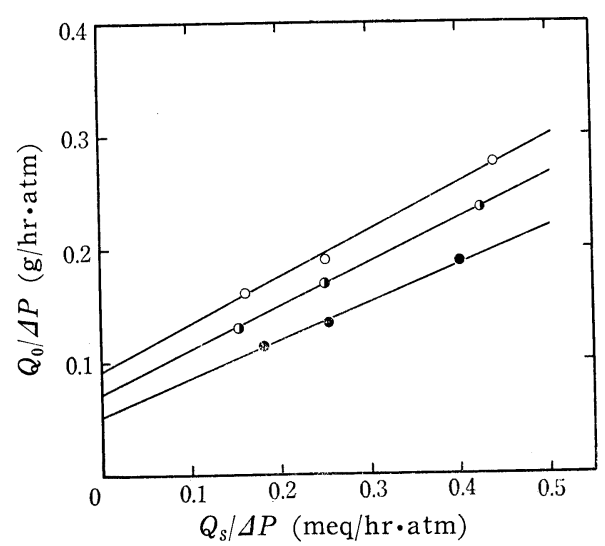

因 2 関係式 (2) とよる実験結果の解析

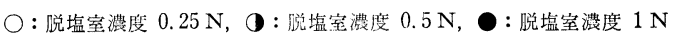

れば $C_{\mathrm{c}}$ が変化しても (2) 式が成立し， $h_{s}$ と $D_{0}$ は定数として 取り报われる。表 2 には単位電解質に随伴して動く水量 $h_{s}(\mathrm{~g} /$ $\mathrm{mol})$ を $H_{s}(\mathrm{~mol} / \mathrm{mol})$ に換算して示した。

このよ5に本実験で使用した膜は架橋度が小さいため $h_{s}, D_{s}$, $D_{0}$ は前報の值よりはるかに大きなっており，相当異なってい るにもかかわらず， $C_{\mathrm{d}}$ さ光一定に保てば $C_{\mathrm{c}}$ は変化して子膜の 特性である $\eta, h_{s}, D_{s}, D_{0}$ の変化は無視され，（1）牤よび (2) 式は成立する。 Frank ${ }^{3)}$ や Kobatake と Fujita ${ }^{4}$ は膜をはさん で濃度差と代力差がある系について電気を流した場合，1枚の膜 の抵抗はそのときの溶液の重心の移動する方向によって大きく異 なり， 2 種類の傾向をもつことを示している。この現象と関連し て電解濃縮の場合を考えると, 溶液の重心移動の方向は脱塩室か
ら濃縮室へとなっているため, 膜の性質の大部分が脱塩室濃度に より支配され， $\eta, h_{s}, D_{s}, D_{0}$ を定数として取り扱うことができる ものと考えられる。

電解濃縮実験の結果, カチオン交換膜とアニオン交換膜の水の 還元輸率 $\tau_{0}$ の和が $h_{s}$ の形で求まっている。そこで非平衡の熱 力学を 1 枚の膜にたいして応用し求められた膜電位 $\Delta \Psi$ と動的 輸率 $t^{*}$ に関する

$$
-\Delta \Psi=\left(2 t_{+}^{*}-1\right) \frac{R T}{F} \ln \frac{a_{ \pm}(2)}{a_{ \pm}(1)}+\tau_{0} R T \ln \frac{a_{0}(2)}{a_{0}(1)}(4)^{8)}
$$

を適用して電流効率 $\eta$ に対応する $t_{+}{ }^{*}+t_{-}{ }^{*}-1$ を求めると表 $2 \sigma$ 最後列となる。これらの值は表 1 の結果注水の項を考虑したもの で，ただ脱塩室濃度に和ける動的輸率を示している。このよ5に して求めた $t_{+}{ }^{*}+t_{-}{ }^{*}-1$ を図 1 から求めた $\eta$ と比較すると全体に 約 0.1 位 $t_{+}{ }^{*}+t_{-}{ }^{*}-1$ の方が大きくなっている。このことは脂 の動的輸率が 1 でないためにイオン交換膜にたいする副イオンカ 濃縮室から脱塩室に流れ, そ結果多少濃縮室濃度が膜の輸率に 影響しているものと考えられる。したがって脱塩室濃度に対伈す る動的輸率が 1 に近ければ近いだけ，その時のクは脱塩室濃度に よって決定されるよ5になると考えられる。 $\eta$ 以外の $h_{s}, D_{s}, D$ も輸率が 1 でないため多少濃縮室濃度の影響が加わっているもの と考えられる。しかし濃縮室濃度の影響はこのように架橋度の小 さい膜に执いても小さく, 定常濃縮に执いてはただ脱塩室濃度气 一定にすれば $\eta, h_{s}, D_{s}, D_{0}$ は定数とみなすことができ，（1）お よび(2)式が常に成立することが明らかとなった。

終始御指導下さった永沢 満教授に深謝します。

$\infty$ ) A. J. Staverman, Trans. Faraday Soc., 48, 176 (1952) 